\title{
"COXA DE NASCENÇA": MISCONCEPTIONS, NORMALCY AND THE AESTHETICS OF DIFFERENCE IN MEMÓRIAS PÓSTUMAS DE BRÁS CUBAS BY MACHADO DE ASSIS
}

\section{KATHRYN SANCHEZ}

University of Wisconsin

Madison, Wisconsin, Estados Unidos

\begin{abstract}
This article analyzes a short yet significant episode in Machado de Assis's novel Memórias Póstumas de Brás Cubas in which the main protagonist-narrator describes the recollections of an amorous encounter with a young girl, Eugênia, who had the misfortune of being born lame. Theoretically informed by the work of Lennard Davis, Rosemarie Garland-Thomson and Mark Osteen, among others, in the field of Disability Studies, this study engages with prior readings of Memórias Póstumas to discuss the embodied experience of disability at the intersection of the aesthetics of beauty and social acceptance within the context of the Brazilian nineteenth century.
\end{abstract}

Keywords: Memórias Póstumas de Brás Cubas; physical disabilities; lameness; social norms.

"COXA DE NASCENÇA": MAL-ENTENDIDOS, NORMALIDADE E A ESTÉTICA DA DIFERENÇA EM MEMÓRIAS PÓSTUMAS DE BRÁS CUBAS, DE MACHADO DE ASSIS

Resumo: Este artigo analisa o breve, mas significante episódio do romance Memórias póstumas de Brás Cubas, de Machado de Assis, no qual o protagonista-narrador descreve 
as suas lembranças de um encontro amoroso com uma jovem moça, Eugênia, que teve o azar de nascer coxa. A partir dos estudos teóricos de Lennard Davis, Rosemarie GarlandThomson e Mark Osteen, entre outros, no campo dos Estudos de Deficiência, esta leitura propõe dialogar com estudos prévios de Memórias póstumas para examinar a experiência corporal de deficiência na intersecção da estética de beleza e de aceitação social no contex to do Brasil do século XIX.

Palavras-chave: Memórias póstumas de Brás Cubas; deficiência física; coxo; normas da sociedade.

1.

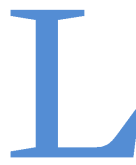

iving in a world of norms, the endeavor to be the same as those around us may be perceived as a core impetus that fuels societal behavior and that leaves no aspect of contemporary life untouched. Within this hegemony of normalcy, particularly over the past few decades, disability studies have engaged the construction of disability and the concept of the normal body as central to understanding the representation of otherness in our society and in the literature that engages with these themes. Assumptions about the universality of the norm and that of the "ideal," a concept that dates back to the seventeenth century, stem from the mythical imaginary of a divine body that represents ultimate beauty, godliness and the sublime, in contrast to all forms of difference or abnormality such as deformity, the grotesque, uncleanliness, and disease.

In the work of Machado de Assis, this concept of the norm versus difference is particularly present in several key texts as articulated through the representation of mental illness (in "O Alienista" and Quincas Borba) and physical disability (the character of Eugênia in Memórias Póstumas de Brás Cubas, the focus of this article). At the nexus of literature and the representation of disabilities, the question at the core of this discussion is, how does Machado's work represent, negotiate and showcase disabilities and therefore contribute to the highlighting or effacing of markers of difference? The term disability itself is 
a nebulous one, encompassing, as Rosemarie Garland-Thomson writes, "ideological categories as varied as sick, deformed, ugly, old, crazy, maimed, afflicted, abnormal or debilitated" (qtd in OSTEEN, 2008, p. 2). As critics David Mitchell and Sharon Snyder (2001, p. 15) develop, in literature and film, disability has an "uneasy home," despite its prominence in narrative discourses. There is a relative absence of critical commentary prior to the advent of disability studies, "literary and historical texts have rarely appeared to offer disabled characters in developed, 'positive' portraits." This leads to the questions, "does literary/cultural studies have anything to offer our apprehension of disability other than demeaning portraits of disabled people in history and the archive? [...] How do humanities scholars justify their work in an area historically dominated by medical and scientific concerns?" (MITCHELL; SNYDER, 2001, p. 15-16).

Throughout literary history, an array of disabled characters has emerged and when examined as a whole, constitutes a varied survey of mostly stereotypical images. These characters, considered to be abnormal in relation to perceived societal standards, for the most part reduce these protagonists to being the bearers of a physical or mental defect, depriving them of a fuller literary characterization. Often the correlation between markers of outward abnormality and character flaws are common tropes that result in the creation of evil literary figures deprived of human qualities and integrity, outcast from the diegetic society, even if they play a central role in the textual plot. Among these iconic, disabled literary characters, whose existence surpasses the boundaries of national literary traditions, is the crippled Greek god Hephaestus, as depicted in Homer's epics the Illiad and the Odyssey; Shakespeare's murderous, power-hungry Machiavellian, hunchbacked king, Richard III; the limping, crooked-backed, sexually vigorous women of Montaigne's essay "Of the Lame or Crippled" (Book III, Chap. XI); the disfigured title character from Gaston Leroux's 1910 novel The Phantom of the Opera, Erik; the one-legged, revenge-seeking, Captain Ahab in Herman Melville's Moby-Dick; the severely hunchbacked, disfigured and deaf Quasimodo in Victor Hugo's The Hunchback of Notre Dame; little crippled Timothy Cratchit "Tiny Tim" in Charles Dickens' 1843 novella $A$ Christmas Carol; and the popular comic book hero, the paraplegic Professor X, founder of the X-Men; to name but a few of this diverse group of literary disabled characters of international renown. In Luso-Brazilian 
literature, we likewise hold our own motley crew of disabled characters that play a visible role in works by authors such as José de Alencar, Machado de Assis, Camilo Castelo Branco, Eça de Queirós, Guimarães Rosa, Miguel Torga, José Saramago and António Lobo Antunes, among the most prominent examples from the nineteenth century to the present.

2.

One of the early chapters of Memórias Póstumas de Brás Cubas is pointedly titled "Coxa de nascença" (ASSIS, 1992, p. 64): the eligible bachelor Brás Cubas, having recently returned from Europe because of his mother's failing health and imminent death, is being enticed by his father to explore future prospects of marriage and a political career. Following his mother's death, he isolates himself, against his family's will, in Tijuca in an old family house, steeped in melancholy, and it is under these circumstances that Brás Cubas is sought out by a family friend of his childhood, Dona Eusébia, and a "galante episódio" of 1814 resurfaces: the young Brás Cubas, as a nine-year old child, caught Dona Eusébia in an embrace in a little thicket at dusk with the dignified forty-seven year old Dr. Vilaça, married and a father (ASSIS, 1992, p. 37, Chap. XII). Now, some seventeen years later, Brás visits Dona Eusébia and meets her daughter, very obviously signaled in the narrative as the fruit of Dona Eusébia's illicit relationship with Dr. Vilaça, Eugênia, "a flor da moita," as the narrator refers to her with insistence. ${ }^{1}$

Nothing extraordinary occurs in the scene that follows: flirtatious glances, smiles and the mother's praise of the daughter. The narrator in his recollections refers to her "graça virginal" - a young woman ripe for conquest, and his playful mind imagines that behind her smile and shining eyes, in her brain "lhe estivesse a voar uma borboletinha de asas de ouro e olhos de diamante..."

\footnotetext{
${ }^{1} \mathrm{~K}$. David Jackson suggests an interesting interpretation of this scene where Dr. Vilaça courts Dona Eusébia in the garden with lines that Brás later identifies as from the Jewish playwright António José da Silva born in colonial Brazil (1705-1739). Jackson (2015, p. 158) speculates that "Brás's discovery may have played a role in his later rejection of Eugênia, the illegitimate daughter of the couple the young Brás disturbs in the garden."
} 
(ASSIS, 1992, p. 62, Chap. XXX). The scene then segues to an unusual incidence with a black butterfly: its presence disconcerts Dona Eusébia, who screams, jumps up and curses the creature (Chap. XXX), leaving her breathless and somewhat embarrassed. In this early part of the episode, Machado's narrative creates an intricate, subtle analogy between Eugênia's birth and the encounter with the black butterfly: the reference to Eusébia "ofegante, um pouco envergonhada" (ASSIS, 1992, p. 62, Chap. XXX) after she cursed the black butterfly could also apply to Eusébia's sexual encounter (or encounters) with Dr. Vilaça, the discovery that she is pregnant with his child, Eugênia's birth and the diagnosis of her birth defect. The parallel with Eugênia's lameness, yet to be revealed, is all too apparent: in the next chapter Brás relates another encounter with an equally black but larger butterfly, and, after a narrative digression, Brás concludes by stating his satisfaction of being superior to butterflies. For Roberto Schwarz (1990, p. 87), the second, larger butterfly represents the lingering persistence of the young girl in his memory. Symbolically Brás kills the butterfly, reiterating its birth defect: "creio que para ela era melhor ter nascido azul" (ASSIS, 1992, p. 63, Chap. XXXI). An implicit foreshadowing of Eugênia's birth deformity: unrealistic and illogical, this lightweight philosophical appreciation of the black butterfly, a source of superstition, fear and ultimately death, is the link to the revelation of Eugênia's physical birth disability, "coxa de nascença." K. David Jackson links the butterfly's mocking attitude in posing on his father's portrait to Brás's previous expression of the desire to be a father when he had observed Dona Eusébia giving Eugênia a tender kiss, an act Jackson perceives as Brás subconsciously referring to his lost chance of fatherhood: when he discovers that she has been lame since birth, she is likened to "a golden butterfly blackened by physical disability" (JACKSON, 2015, p. 91).

This pattern that flows seamlessly from the butterflies to the physical defect of the young girl, appears as a variation of the structure of the narrative that José Luiz Passos (2007, p. 129) identifies as a movement of examplegeneralization-example, or "compulsive digression," one of the many formulas used by the narrator to explain the behavior of characters and their thoughts. As Passos (2007, p. 129) writes: "O esforço analítico de Brás apresenta, com indiferença, dados e introspecções para deleite e juízo do leitor. O narrador se retira da cena e deixa o julgamento em nossas mãos." The revelation of Eugênia's disability is staged with conjoint elements of surprise and 
embarrassment, and as the narrator withdraws, the judgment is indeed left in our hands. Forgoing personal adornments, Eugênia appears exposed in all her simple naturalness: "desataviou-se nesse dia por minha causa," Brás Cubas recalls (ASSIS, 1992, p. 64, Chap. XXXII). Without the gold earrings of the first previous encounter, Eugênia appears wearing a simple, white muslin dress, no brooch, only a mother-of-pearl button, no bracelets. Her simplicity transfers over to her state of mind; Brás comments on her clear ideas, simple mannerisms, natural grace and poise (ASSIS, 1992, p. 64, Chap. XXXII). For Schwarz (1990, p. 82), the calculated simplicity of Eugênia's appearance has two levels of interpretation: on the one hand, divesting her person of adornments shows she knows her social position; on the other hand, it is a reminder of essential parity between individuals. It is there, in all her simplicity, that her vulnerability is exposed when the mother Dona Eusébia suggests showing Brás Cubas their little estate. As they leave the veranda and walk around the grounds, Brás notices what he refers to as a temporary state, "notei uma circunstância," a phrase that captures the narrator's point of view, his unsuspecting perception and concern. Brás relives the scene: "Eugênia coxeava um pouco, tão pouco, que eu cheguei a perguntar-lhe se machucara o pé" (ASSIS, 1992, p. 64, Chap. XXXII). While the mother remains silent, the daughter herself responds "sem titubear": "- Não, senhor, sou coxa de nascença" (ASSIS, 1992, p. 64, Chap. XXXII). The dissimulating performativity of the previous encounters that had masked Eugênia's physical flaw becomes apparent: during their first meeting, she had barely responded to Brás's "gesto de cortesia" and had approached her mother's chair slowly (ASSIS, 1992, p. 62, Chap. XXX); that next time he arrived for dinner he found her already seated at the dinner table (ASSIS, 1992, p. 64, Chap. XXXII). Brás Cubas reinforces Eugênia's confession of her limp, a confession he views with puzzlement given the prior effort to hide, he believes, the defect: "Talvez fosse para encobrir o defeito; mas por que razão o confessava agora?" (ASSIS, 1992, p. 64, Chap. XXXII). Only in this section of the Eugênia episode does Brás Cubas show remorse for his blunder, even if it is feigned: "Mandei-me a todos os diabos; chamei-me desastrado, grosseirão. Com efeito, a simples possibilidade de ser coxa era bastante para lhe não perguntar nada" (ASSIS, 1992, p. 64, Chap. XXXII). The reader remains just as puzzled as Brás Cubas: was Eugênia's prior behavior, both concealing her impairment and confining her movements to those that did not reveal her limp, an act of passing, 
to coopt a concept typically germane to black and lesbian or gay cultures? Expecting her disability to be unacceptable, Eugênia's "coming out" is a courageous act with inevitable consequences: the loss of both her love interest and the possibility of social advancement. ${ }^{2}$

This mise-en-scène is not gratuitous and can be perceived as one of Machado's discrete (eventually) incidents of showing and not telling, keeping in mind his criticism of Eça de Queirós, whom he condemns of being overly concerned with the mandates of Realism, "aquela reprodução fotográfica e servil das coisas mínimas e ignóbeis", "o escuso e o torpe [...] tratados com um carinho minucioso e relacionados com uma exação de inventário," an author who "não esquece nada, e não oculta nada" (ASSIS, 2013, p. 468-469).

Recalling these circumstances with Eugênia, Brás wonders why, if these previous scenes had been to hide her disability, was she then so prompt to articulate it? Indeed, only under the narrator's gaze and his questioning does her limp become visible and articulated. As Bill Hughes (1999, p. 158) argues, in general terms "the impaired body [of the disabled] is rendered disorderly by the 'positive' observational practices that produce $\mathrm{it}^{\prime}$ - a concept that rings particularly true in the context of Brazil in the 1880s with the popularity of positivist thought.

3.

How can we interpret this physical defect within the Machadian characterization of his (especially female) protagonists and within this novel in particular? For Maria Luisa Nunes (1983, p. 124), Brás Cubas perceives Eugênia's beauty juxtaposed to her lameness as "a terrible enigma." But that would be taking Brás for a reliable narrator, which he is not. As K. David Jackson (2015, p. 11) indicates, "Like a chess master, Machado frequently misleads and even entraps inattentive readers by concealing deeper intentions through inferences, unreliable narrators and irony, characteristics intensified in

${ }^{2}$ Here I am inspired by Simi Linton's (1998, p. 17-22) section "Speaking about Overcoming and Passing" in Claiming Disability. 
Brás Cubas's posthumous memoirs." With this in mind, how sincere could Brás's references to Eugênia as the goddess Venus or Diana possibly be, considering the fact that the juxtaposition of the adjectives "coxa" and "manca" have an oxymoronic ring: "Vênus Manca" or "coxa de Diana," both goddesses portrayed as beautiful and youthful. In this designation, Machado's irony focuses in on the ideal mytho-poetic body that cruelly moves Eugênia further from this visualized ideal of the divine body - not attainable by a human or even more so by one with an aesthetic defect negatively portrayed. If she is, as Maria Luisa Nunes (1983, p. 125) claims, among the first of Machado de Assis's love symbols, then she is an imperfect one, and not even Quincas Borba's humanitismo that postulates self-care first and foremost, could save this relationship based on appearances. Brás Cubas's rejection of Eugênia is equivalent to turning his back on the one decent, selfless woman who would give his life true love and hence true meaning. For Reginald Daniel (2012, p. 130), the discovery of Eugênia's slight limp "highlights her assets": she is "the one wholesome character in the novel and the only one with apparently untainted motives." This is similar to Schwarz's interpretation of "O pior é que era coxa" juxtaposed to Brás's enumeration of attributes of her physical beauty: "Uns olhos tão lúcidos, uma boca tão fresca, uma compostura tão senhoril; e coxa!" (ASSIS, 1992, p. 65, Chap. XXXIII). Schwarz (1990, p. 90) writes: "Estas prendas, que são o que retém o rapaz, transformaram-se em negativo naturalmente por pertencerem a uma criatura pobre e por criarem um impasse moral e sentimental para o filho-família."

Unlike Dona Plácida, Eugênia does not focus on overcoming her social position as a child born out of wedlock. Through her mother's estate (most likely bequeathed by Dona Eusébia's deceased lover Dr. Vilaça), Eugênia has the appearances of a respectable woman of society. Where she differs is her moral integrity, and as far as the narrative reveals, her dignity and unselfish character. Eugênia remains dignified through the end of the novel even when living in poverty. When Brás, distributing alms to the poor, meets her again, she holds her head high: "Ergueu logo a cabeça, e fitou-me com muita dignidade. Compreendi que não receberia esmolas da minha algibeira, e estendi-lhe a mão, como faria à esposa de um capitalista" (ASSIS, 1992, p. 175, Chap. CLVIII). The reader (nor Brás Cubas) never finds out how Eugênia ended up living in misery and what would have become of her mother and the family estate. The only 
information that Brás culls from this chance encounter is his perception that she had remained "tão coxa como a deixara, e ainda mais triste" (ASSIS, 1992, p. 175, Chap. CLVIII), facts that the narrator mentions again at the close of the chapter, reiterating and reducing Eugênia to her lameness and sadness.

4.

To understand Eugênia's position in society, placed at its margins, the reader needs to return, as Lennard Davis (1995, p. 23) writes in his seminal text Enforcing Normalcy, "to the concept of the norm, the normal body" and how society has constructed normalcy: the 'problem' is not the person with a marked difference, "the problem is the way that normalcy is constructed to create the 'problem' of the disabled person" (DAVIS, 1995, p. 24). While Eugênia recognizes much to her moral and affective suffering the social consequences of this aesthetic impairment, never in the narrative is there any indication of physical disablement. Does she not walk with ease around the family "chácara" in company of her mother and Brás Cubas? If Brás Cubas asks "por que coxa se bonita?" the inquiring reader can also ask, why coxa? Unlike blindness, deafness, stuttering or other communicative disabilities, a limp does not disturb "the complex web of subtle exchanges upon which communication rituals depend" (THOMSON, 1997, p. 37) and only barely, if at all, "impedes quotidian functions required by the elaborately structured codes of acceptable social behavior" (THOMSON, 1997, p. 37).

Brás Cubas's views of and interactions with women justify critics labeling him a misogynist. Maria Manuela Lisboa (1996, p. 58) refers to his voice as "characterized by apparently candid if vicious honesty and undisguised misogyny," dismissing or skipping over "any mention of a good woman, preferring to dwell upon his acquaintance with relatively bad ones" (LISBOA, 1996, p. 59). She concludes: "The possibility of the existence of a genuinely good woman and furthermore an influential one is problematic for the male optic which prefers to concentrate instead on those of the sex more likely to substantiate the misogyny of the narrator" (LISBOA, 1996, p. 59). Rather than a mixture of philosophy and humor, as is often the case throughout this novel, 
here the attitude of the narrator blends philosophy and cruel realism, where brutal honesty expresses that which should be discretely overlooked. Decades prior to Freud's (1958, p. 87) essay on "The 'Exceptions'", Eugênia disavows his notion that deformities of character are the results of physical ailments. As such, we must conclude that Eugênia's slight limp is a minor blemish on an honorable young woman, symbolically representative of her birth out of wedlock, a socially-perceived curse on an innocent child, an uncomfortable way of thinking in line with nineteenth-century social Darwinism that led to scapegoating those who were considered different.

Eugênia's limp overrides all other physical characteristics and character traits, regardless of how light and even unperceivable at first. Once discovered, the narrator narrows in on this deviant characteristic that, as Edward Jones (1984, p. 9) discusses in relation to disabilities in general terms, overwhelms all of a person's other, unmarked aspects, linking "the mark to a central aspect of the marked person's identity or dispositional make-up." In Eugênia's case, the markedness of this one characteristic is highlighted in the title of the chapter, "Coxa de nascença," quoted in the title of my article - as I too participate in this selective labeling of this fictional character - and in the opening words of several of the subsequent chapters in Machado's novel. During the nineteenth century, theories of the body having a unique identity that coincided with its essences were in vogue (e.g. the novelty of fingerprinting ${ }^{3}$ ). As Lennard Davis (1995, p. 31) writes, in the spirit of the period, "marks of physical difference became synonymous with the identity of the person," an identity that is "unchangeable and indelible as one's place on the normal curve." This permanence is cruelly implied in a subsequent chapter title in Memórias póstumas, "A propósito de botas" that, as Schwarz discusses, continues the narrator's "festival de maldades" through the emphatic linguistic use of references to feet, boots, cobblers, etc. "O procedimento é bruto, sem prejuízo da sutileza extrema do contexto [...]. [...] a baixeza ostensiva das alusões é também um modo de vexar o leitor e realçar a própria impunidade" (SCHWARZ, 1990, p. 91). Here Machado's irony reiterates Eugênia's condition as a final state without

\footnotetext{
${ }^{3}$ See one of the first attempts to historicize fingerprinting as a method of personal identification, from its discovery in Bengal in 1858 to its public demonstration there in 1877-78, in the tract by Sir William J. Herschel (1916). In the dedication Sir. W. J. Herschel (1916, p. 3) expresses his "warm and continuous admiration of those masterly developments of its original applications" that fashioned the technique as "a weapon of penetrating certainty for the sterner needs of Justice."
} 
remedy and objectifies through the literary discourse her lameness. This reification echoes the notion that Diane Price Herndl (2001, p. 593-594, qtd in OSTEEN, 2008, p. 2) addresses in terms of medical humanities and disability studies in general that err by representing disability and disease as things rather than relations. As the protagonist removes with a sigh of relief his tight boots, Machado's text forces the parallel with the liberating of the protagonist's heart, "lançava eu os olhos para a Tijuca, e via a aleijadinha perder-se no horizonte do pretérito, e sentia que o meu coração não tardaria também a descalçar as suas botas" (ASSIS, 1992, p. 68, Chap. XXXVI). The analogy has a heartless sting to it, drawing direct attention to footwear and to the part of Eugênia's body that became the target of his discomfort. The emphasis on the narrator's gaze in the direction of Tijuca reinforces the spatial distance. Eugênia and Brás Cubas's encounters in Tijuca, at that time considered to be on the outskirts of Rio, draws a parallel with the historical notion of segregated disabled people. As Michel Foucault extensively analyzed in his work on how society perceives abnormality in terms of sexuality, criminality and insanity, marginalized subjects have typically been relegated to the outer parts of society, both physically and figuratively, through forms of confinement/imprisonment, regulation and exclusion. ${ }^{4}$ The novel repeatedly emphasizes this separation between Tijuca and the center of Rio with references to Brás Cubas going down to the city to be reintegrated into his social class and peer community.

5.

There are no possibilities of remedy in Eugênia's future and no prospects of altered beliefs that could modify how her defect is read and that could reduce the stigma, its salience and social treatment. ${ }^{5}$ Unlike Flaubert's club-footed Hippolyte in Madame Bovary, there is no attempt at a remedial operation to align her with the norm: perhaps Machado chose to short-circuit the lesson that science cannot eradicate disability - we simply need to remember that

${ }^{4}$ See, among other studies, Foucault's works (1988; 1994; 1995).

${ }^{5}$ See Jones (1984, p. 36-39) for a theoretical discussion on altering the course of the mark. 
Hippolyte's leg became gangrenous and had to be amputated. Rather, Machado opts for the symbolic representation of the black butterfly that had the misfortune of not being born blue. However, Eugênia's deformity could not be eliminated by the swipe of a towel.

There is no mention of Eugênia's physical suffering or pain, no remedy or effort to mask the inevitability of her condition from birth, her slight limp is purely an aesthetic sign that carries a social stigma the protagonist herself boldly articulates. The interest in what otherwise would be a very banal story of seduction is in the characterization of Eugênia, of whom we know very little, if anything at all, of her motives and thoughts - we are only privy to Brás Cubas's recollections and alleged motivations. This is fitting with a typical literary trend that conceals the voice of the disabled subject (OSTEEN, 2008, p. 7) and other than a few occasional snippets of conversation, Eugênia's point of view is absent as her experience is colonized by Brás Cubas. As Passos (2007, p. 104-114) proposes, the play of memory factors into the tension or conflict between the characters' subjectivity or essence and their appearances, the ambivalence between the internal motives (hidden from themselves, other characters, and the reader) and the public justification of actions, decisions, and even thoughts.

The narrator makes no qualms about reiterating that Eugênia's defect is the cause of his fear, terror even, and his imminent departure, as though summoned by a mysterious, interior voice ("Levanta-te, e entra na cidade") is reminiscent of Saul's Biblical descent to Damascus, as though Brás Cubas's descent from Tijuca were a spiritual awakening and the beginning of his inner transformation (ASSIS, 1992, p. 67, Chap. XXXV). How could he really fall in love with Eugênia and marry her, a lame woman, as indicated in the narrative with euphoric exclamation: "Uma mulher coxa!" (ASSIS, 1992, p. 67, Chap.

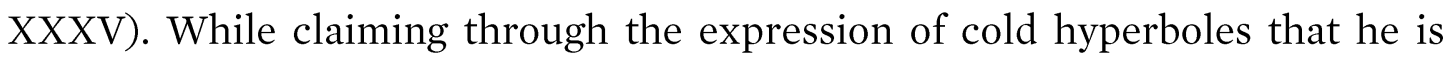
obliged to leave, Eugênia is forthright with pointed honesty, holding back her tears: "Faz bem em fugir ao ridículo de casar comigo" (ASSIS, 1992, p. 67, Chap. XXXV). Despite social differences - according to which, as Schwarz (1990, p. 83) indicates, the value of an individual in a slave-based society rests upon arbitrary recognition of those in power - Eugênia is rejected because of her limp that, as she phrases, would make her a bride or wife vulnerable to scorn. Beyond the initial recognition of the defect that marked her, Eugênia's limp is, to borrow from Edward Jones's (1984, p. 8) theoretical terminology, "noticed 
and recognized as a problem in the interaction or the relationship." Furthermore, Brás's hasty departure stigmatizes Eugênia, her identity has been spoilt and her beauty discredited. 6 Paraphrasing Jones, it can be said that Eugênia cannot be dealt with except in terms that consider her deviant mark as an integral part of her identity. She is the victim of "impression engulfment," considered the essence of stigma (JONES, 1984, p. 9).

Why would Eugênia's slight limp disqualify her from being Brás Cubas's love interest and possible wife? For Schwarz, the limp is merely a pretext since it would not prohibit her from becoming a desirable long-term companion. The social, class and geographic disconnect that Brás perceives separates him from Eugênia's situation and plight he controls, a disconnect that is amplified by the discovery of her physical defect, lame from birth. As Schwarz (1990, p. 88) writes, "[Brás Cubas] despejará sobre a deformidade natural os maus sentimentos que lhe inspira o desnível de classe [...]. Assim, além de não ser a verdadeira, a razão alegada não convence, e firma o clima de desconversa e desculpa esfarrapada..." Regardless of the reason or reasons vocalized, Brás Cubas dismisses Eugênia by relocating himself to the city and fails to provide her with the opportunity of betterment. Reading this episode, Earl Fitz (2015, p. $120 ; 121)$ sees Eugênia's missed opportunity as representative of what "the old, socially sclerotic Brazil is failing to nurture," "the Brazilian elite's dismissal of the rest of the nation, and most particularly of Brazil's young women who [...] could well prove to be invaluable to Brazil's future development and success."

Fitting with nineteenth-century Darwinian pseudoscientific tenants, Eugênia's dismissal projects to the strengthening of an elitist nation, akin to the soon-to-be-widespread theories of eugenics. Earl Fitz (2015, p. 172-173, fn 26) suggests that Eugênia's name recalls the term "eugenics" and that possibly Machado "thinking of its emphasis on the improvement of a type or entity, decided, in the manner of what would later become known as 'euthenics', to make a nonracial and more environmental use of it in his gender-sensitive and progress-oriented novels." The interpretation is seductive, even if the term "eugenics" gained wide currency slightly after the publication of Memórias póstumas. As Davis (1995, p. 32) indicates, Sir Francis Galton - cousin of Charles Darwin - is thought to have coined the term in 1883, the same year as

${ }^{6}$ Likewise see Edward Jones (1984, p. 8) on the implications of the stigmatizing process that link the mark to "dispositions that discredit the bearer, i.e. that 'spoil' his identity." 
Alexander Graham Bell's eugenicist speech, Memoir upon the Formation of a Deaf Variety of the Human Race, analogous to the Frankenstein fear that disability engenders disability. To move a nation forward, to keep it strong mentally and physically, each new generation would need to derive chiefly from the fitter members of the previous generation. This resonates with the widely discussed metaphor of the body according to which a nation relies on the fitness of its inhabitants. Regardless of whether the term circulated prior to the publication of Memórias Póstumas, Machado's text is imbued with the then current theories of social evolution that served to place the less fit along the wayside as evolutionary defectives to be surpassed by natural selection. In this Machado's text resonates with the budding concept of the valued body of modernity and the process of rationalization that sought, through "negative eugenics" (cf. GARLAND-THOMSON, 2006, p. 78-79), to smooth out human "irregularities" toward the building of a robust, industrial-minded, developed capitalist world. In Eugênia's case, only for a fleeting moment does she acquire social status when Brás Cubas, in the scene referred to above, meets her again years after their relationship is over and extends to her his hand (ASSIS, 1992, p. 175, Chap. CLVIII).

6.

When Brás Cubas announces his departure, Eugênia reinforces his decision, all the while clearly denouncing his excuses: "digo-lhe que faz bem" (ASSIS, 1992, p. 67, Chap. XXXV). The reader might expect the final segment of this cruel goodbye to project Eugênia's pain and Brás Cubas's placidness at this cold-hearted departure, but this is not the case: the scene closes on Eugênia, fully in command of the situation. Rather than the supplicating look Brás Cubas (and the reader) might expect, Eugênia's last expression is one of dominance, leaving, through a bizarre Machadian twist of sentiments, Brás Cubas dissatisfied and bitter (ASSIS, 1992, p. 67, Chap. XXXV). But, let us not forget, as Alfredo Bosi (1999, p. 10) develops, "olhar tem a vantagem de ser móvel." This is Machado's well-known "enigma do olhar" (BOSI, 1999), transposed from narrator or author to protagonist to reader. This episode, with a tragic outcome 
for Eugênia, illustrates in typical Machadian fashion, not only the importance of keeping up social appearances, but also to do so imperatively by holding on firmly to that which Bosi (1999, p. 85) refers to as "as instituições cardiais... O Matrimônio e o Patrimônio; e respectivamente, o Adultério e o Logro." In order to do that, dissimulation and deceit are a necessity: Brás Cubas could flirt with Eugênia, but marriage would be out of the question, barring her from all prospects of "Matrimônio," "Patrimônio," "Adultério" or "Logro."

The power of the narrator-protagonist reaches its peak when he abruptly declares, (presumably referring to himself, the narrator and his readers, "as cinco ou dez pessoas que [o] leem"): "acabemos de uma vez com esta flor da moita" (ASSIS, 1992, p. 66, Chap. XXXIV). Creating a precedent in LusoBrazilian literature, which will find a reincarnation in Clarice Lispector's narrator Rodrigo S. M. in A hora da estrela or José Saramago's narrator in $O$ ano da morte de Ricardo Reis, Machado's agent is empowered by his narratorial position to be carried out with the now bothersome Eugênia. This performative call to action to "finish off the flower of the thicket" at the end of the chapter immediately prior to breaking off his relationship with Eugênia and destroying her prospects of marriage and social advancement, is justified in the following chapter through his obedience to his father, the convenience of embracing a political career, the constitution, his chosen bride, even his horse (ASSIS, 1992, p. 67, Chap. XXXV). Daniel (2012, p. 129) sees Brás Cubas as acting out of respect for Eugênia, sparing her from his sexually predatory advances, because of her lameness and dignity. This interpretation can indeed ring true given the appearances upheld, but seems far distinct from Brás Cubas's reality and inner monologue that only focus on his future career, personal comfort, social life and pleasure (cf. ASSIS, 1992, p. 67, Chap. XXXV).

In Machado's novel, where no situation or circumstances are ever gratuitous but rather contain multiple levels of interpretation and provocation, the concept of "defeito" or defect is insinuated and explicitly mentioned throughout: character flaws are noted in others and of the narrator himself, but only one physical defect, that of the most perfect young girl, Eugênia. At the beginning of the novel, the narrator sees his self-indulgence and love of glory in the publicizing of the "Emplasto Brás Cubas" as a "defect" in the eyes of more modest people (ASSIS, 1992, p. 18-19, Chap. II). Marcela, in whom Brás Cubas places his trust (and his money - "quinze meses e onze contos de réis; nada 
menos" [ASSIS, 1992, p. 44, Chap. XVII]), "podia ter defeitos, mas amava-me..." remembers the narrator. Similarly, about another of his later love interests, Nhã-loló, he remembers that what she lacked in elegance she made up for with her superb eyes "que [...] só tinham o defeito de se não arrancarem de mim," then the narrator adds with irony "exceto quando desciam ao prato; mas Nhãloló comia tão pouco, que quase não olhava para o prato" (ASSIS, 1992, p. 125, Chap. XCIII). The narrator views himself, even in his fourth revised and corrected edition, contaminated by "descuidos e barbarismos; defeito que, aliás, achava alguma compensação no tipo, que era elegante, e na encadernação, que era luxuosa" (ASSIS, 1992, p. 69, Chap. XXXVIII); and 'once the complicity wears off and boredom sets in, is the reader not "o maior defeito deste livro" (ASSIS, 1992, p. 103, Chap. LXXI)? Not even the implied reader escapes from Brás Cubas's libel and slander. As such, all aspects of the novel appear soiled, least of which is not Brás Cubas himself, whose life relies on posthumous retouching and revolves around the unsuccessful invention of his "emplasto," his failure to contribute to humanity with a cure for melancholy beyond the words he writes, and his failure to engender any offspring due to a string of unfruitful, short-lived relationships.

The social process of disabling (that involves observing, labeling and categorizing all forms of abnormalities) surfaced concurrently to a greater discussion of modern notions, practices and discourses such as citizenship, nationality, race, gender, sexual orientation and criminality, from the late eighteenth and nineteenth centuries on, and opens new approaches to and justifications of homogenization, what has been considered the norm - of which Foucault wrote extensively. It is not purely coincidence that, as several critics have pointed out, Machado's main novels, Memórias Póstumas, Quincas Borba, and Dom Casmurro, are published within a reformed institution for the administration of hygiene and sanitation, at a nexus between medical progress, clinical diagnosis, and literary modernity: these works are, however, neither a result nor a reflection of these societal changes but a reaction that blends criticism with suspicion. The writing of the short story "O Alienista" likewise corresponds with the foundation of the chair of mental and nervous system illnesses at Hospice Pedro II, a first attempt at rationalizing psychiatric treatment (PASSOS, 2007, p. 130). As Earl Fitz (2015, p. 112) rightly states, Machado's extraordinary fifth novel "militates in favor of new thinking about 
women and their place in a fast-progressing Brazil." This is especially relevant if we remember and accept, as Davis (1995, p. 41) suggests, "that novels are a social practice that arose as part of the project of middle-class hegemony, [in which] plot and character development tend for the most part to pull toward the normative." With this in mind, through Eugênia's limp as a mark of difference, this study unravels the literary representation of the embodied experience of disability in order to pry open its "uneasy home" in Machado's work, at the intersection of the aesthetics of beauty, love, equality and normalcy.

\section{References}

ASSIS, Machado de. Memórias Póstumas de Brás Cubas. São Paulo: Ática, 1992. Literatura realista. O primo Basílio, romance do Sr. Eça de Queirós. Porto 1878. In: AZEVEDO, Sílvia Maria; DUSILEK, Adriana; CALLIPO, Daniela Mantarro (Orgs.). Machado de Assis - Crítica literária e textos diversos. São Paulo: Editora Unesp, 2013. p. 467-474.

BOSI, Alfredo. Machado de Assis: O enigma do olhar. São Paulo: Editora Ática, 1999.

DANIEL, G. Reginald. Machado de Assis: Multiracial Identity and the Brazilian Novelist. University Park, Pennsylvania: The Pennsylvania State University Press, 2012. DAVIS, Lennard J. Enforcing Normalcy: Disability, Deafness and the Body. London; New York: Verso, 1995.

FITZ, Earl E. Machado de Assis and Female Characterization: The Novels. Lewisburg: Bucknell University Press, 2015.

FOUCAULT, Michel. Discipline and Punish: The Birth of the Prison. Trad. Alan Sheridan. New York: Vintage Books, 1995.

Madness and Civilization. A History of Insanity in the Age of Reason. Trad. Richard Howard. New York: Vintage Books, 1988.

The Birth of the Clinic: An Archaeology of Medical Perception. Trad. A. M. Sheridan Smith. New York: Vintage Books, 1994.FREUD, Sigmund. Some CharacterTypes Met With in Psycho-Analytic Work [1915]. In: —_. On Creativity and the Unconscious: Papers on the Psychology of Art, Literature, Love, Religion. Intro. Benjamin Nelson. New York; Hagerstown; San Francisco; London: Harper \& Row, 1958. p. 84-110. 
GARLAND-THOMSON, Rosemarie. Welcoming the Unbidden: The Case for Conserving Human Biodiversity. In: LANG, A. S.; TICHI, C. (Eds.). What Democracy Looks Like. New Brunswick: Rutgers University Press: 2006. p. 77-87.

HERNDL, Diana Price. Disease Versus Disability: The Medical Humanities and Disability Studies. PMLA, n. 120, p. 593-597, 2005.

HERSCHEL, William J. The Origin of Finger-Printing. London: Oxford UP, 1916.

HUGHES, Bill. The Constitution of Impairment: Modernity and the Aesthetic of Oppression. Disability \& Society, v. 14, n. 2, p. 155-172, 1999.

JACKSON, K. David. Machado de Assis: a Literary Life. New Haven; London: Yale University Press, 2015.

JONES, Edward et al. Social Stigma: The Psychology of Marked Relationships. New York: W. H. Freeman and Company, 1984.

LINTON, Simi. Claiming Disability: Knowledge and Identity. Foreward Michael Bérubé. New York: New York University Press, 1998.

LISBOA, Maria Manuel. Machado de Assis and Feminism: Re-Reading the Heart of the Companion. Lewiston; Queenston; Lampeter: Edwin Mellen Press, 1996.

MITCHELL, David T.; SNYDER, Sharon L. Narrative Prosthesis: Disability and the Dependencies of Discourse. Ann Arbor: University of Michigan Press, 2001.

NUNES, Maria Luisa. The Craft of an Absolute Winner: Characterization and Narratology in the Novels of Machado de Assis. Westport, Connecticut; London, England: Greenwood Press, 1983.

OSTEEN, Mark (Ed.). Autism and Representation. New York; London: Routledge, 2008.

PASSOS, José Luiz. Machado de Assis: O romance com pessoas. São Paulo: EdUSP, 2007.

SCHWARZ, Roberto. Um mestre na periferia do capitalismo: Machado de Assis. São Paulo: Duas Cidades, 1990.

THOMSON, Rosemarie Garland. Extraordinary Bodies: Figuring Disability in American Culture and Literature. New York: Columbia University Press, 1997.

KATHRYN SANCHEZ is Full Professor of Portuguese and works with Portuguese literature of the 19th and 20th Century, Brazilian film and popular culture, and the representation of Brazil and Brazilians in the United States. She frequently teaches Portuguese and Brazilian literature and culture, an introductory course to Latin America, and courses on race, gender and sexual difference in relation to the Portuguese-speaking world. Her current research project is a book length study that re-evaluates Carmen Miranda as an icon of tropical otherness in the United 
States. Her latest book is Creating Carmen Miranda: Race, Camp, and Transnational Stardom (Vanderbilt University Press, 2016). She has published articles in Portuguese Studies, Bulletin of Hispanic Studies, Quadrant, Santa Barbara Portuguese Studies, World Literature and Its Time, Queirosiana and Portuguese Literary and Cultural Studies. She served as the President of the American Portuguese Studies Association (2008-2010). E-mail: kathryn.sanchez@wisc.edu

Recebido: 02.05.2018

Aprovado: 23.07.2018 